Article

\title{
Overview of Dynamic Facility Layout Planning as a Sustainability Strategy
}

\author{
Pablo Pérez-Gosende ${ }^{1}$, Josefa Mula ${ }^{1}(1)$ and Manuel Díaz-Madroñero ${ }^{1, *}$ \\ Research Centre on Production Management and Engineering (CIGIP), Universitat Politècnica de València, \\ 46022 Valencia, Spain; pabpego3@upv.es (P.P.-G.); fmula@cigip.upv.es (J.M.) \\ * Correspondence: fcodiama@cigip.upv.es
}

Received: 16 August 2020; Accepted: 5 October 2020; Published: 8 October 2020

check for updates

\begin{abstract}
The facility layout design problem is significantly relevant within the business operations strategies framework and has emerged as an alternate strategy towards supply chain sustainability. However, its wide coverage in the scientific literature has focused mainly on the static planning approach and disregarded the dynamic approach, which is very useful in real-world applications. In this context, the present article offers a literature review of the dynamic facility layout problem (DFLP). First, a taxonomy of the reviewed papers is proposed based on the problem formulation current trends (related to the problem type, planning phase, planning approach, number of facilities, number of floors, number of departments, space consideration, department shape, department dimensions, department area, and materials handling configuration); the mathematical modeling approach (regarding the type of model, type of objective function, type of constraints, nature of market demand, type of data, and distance metric), and the considered solution approach. Then, the extent to which recent research into DFLP has contributed to supply chain sustainability by addressing its three performance dimensions (economic, environmental, social) is described. Finally, some future research guidelines are provided.
\end{abstract}

Keywords: facility layout problem; dynamic layout; literature review; mathematical programming; sustainability; supply chain management

\section{Introduction}

The facility layout problem (FLP) is a well-known design problem that deals with the physical arrangement process of all the production factors that comprise the production system insofar as the organization's strategic objectives are adequately and efficiently met. Within the business operations strategies framework, the FLP is considered one of the most important design decisions [1,2]. It also has a significant impact on the efficiency and productivity level of manufacturing systems [3-5], and has, therefore, become a widely discussed topic in the scientific literature since the second half of the 20th century [6]. To date, however, its contribution to sustainability within the supply chain management framework is not sufficiently highlighted in the literature.

Although sustainable supply chain management (SSCM) is a relatively new concept [7], it has increasingly drawn the attention of business and academia [8-11]. Sustainability has been interpreted by industry and scientific literature with different terms and approaches [12]. Nevertheless, the common point in these definitions is their consideration of three fundamental pillars, namely economic, environmental, and social, which have become the so-called triple bottom line of sustainability [7,13-15].

The environmental dimension of sustainability lies in the conservation of the natural environment and the conscious use of its resources so that they remain for future generations [16]. The social dimension is related to human capital and actions performed to safeguard its health and safety, respect its rights and ethical principles, and increase social well-being [17]. The economic dimension is 
associated with increasing cost-efficiency, business opportunities, operational stability, and economic well-being [18].

Due to growing pressure from investors, clients, and governments to reduce the environmental impact of their operations, companies have increased their commitment to incorporating sustainable practices in their operations management $[12,15]$. However, there is still some way to go in the gradual transition from traditional to sustainable supply chains. Opportunities for improvement need to be exploited from all possible angles, and with that goal in mind, to the authors' opinion, introducing the triple bottom line perspective into facility layout planning may result in a significant contribution.

When the layout is planned according to the assumption that demand will remain constant throughout the planning horizon, the problem is known as the static facility layout problem (SFLP). This approach has been recommended for production systems with low rearrangement costs [19]. However, when a single design is contemplated, it may be impractical in most industrial sectors because it is unlikely that the materials flow remains unchanged over time. Companies need to constantly adapt to changing market needs. To do so, they increase or contract their productive capacity, change or update its technology, create new products and services, and improve or implement new processes. In this context, the need to sufficiently adopt dynamic layouts is almost mandatory [20]. With this approach, named the dynamic facility layout problem (DFLP), an optimal layout is adopted for each period so that all the material handling costs and the facilities rearrangement costs are minimized [21-23].

A recent study showed that layout planning performed by the dynamic planning approach has been less discussed in the scientific literature [6]. Furthermore, since 2012, to the authors' knowledge, there has not been published any other literature review focused on DFLP [24]. By considering all this, as well as the growing trend in literature review studies on SSCM combined with different related topics [12-15,25-28], this article presents an overview of the DFLP literature and its contribution to sustainability in supply chain management from the triple bottom line perspective in the last 10 years (2010-2019).

The remainder of the paper is structured as follows. Section 2 describes the review methodology. Sections 3 and 4 respectively present the current trends in DFLP formulation and DFLP mathematical modeling. Section 5 discusses which sustainability dimensions in supply chain management have been included in DFLP formulation according to the revised literature. Future research directions are provided in Section 6 and, finally, Section 7 offers the study conclusions.

\section{Review Methodology}

To accomplish the study objective, we adopted the systematic literature review (SLR) process introduced by Denyer and Tranfield [29] as it has been effectively proven in other recent studies related to the supply chain management area [30-32]. This review methodology includes five steps: (i) Formulating research question(s); (ii) identifying studies; (iii) selecting and evaluating studies; (iv) analyzing and synthesizing; (v) presenting the results and discussion [29].

As a starting point for our SLR process, the following research questions (RQ) were formulated: (RQ1) What is the current state of knowledge on problem formulation and mathematical modeling, and the solution approach to DFLP in the last decade?; (RQ2) what has DFLP contributed to SSCM from a triple bottom line perspective?; (RQ3) what are the gaps and future research directions that can be identified based upon existing works?

The relevant bibliography was collected considering the scientific articles published in the journals indexed in the Science Citation Index Expanded (SCIE) of the Web of Science (WoS), which is the world's leading scientific citation search and analytical information platform [33]. The time window considered was 2010-2019. The employed keywords were: Facility(ies) layout problem; facility(ies) layout design; facility(ies) layout planning; plant(s) layout design; facility(ies) design; facility(ies) planning; dynamic layout; cyclic layout; robust layout; and reconfigurable layout. According to these search criteria, the WoS indicated 59 related scientific articles. 
After collecting these papers, their abstracts, methodologies, main results, and conclusions were thoroughly examined to determine whether they were relevant to the research questions. This process was based on the analysis of the following exclusion criteria: (a) Papers beyond the operations management scope; (b) papers in which DFLP was not approached by mathematical optimization models.

As a result of this filtering, the remaining 44 articles were analyzed and synthesized to create a taxonomy that integrated, on the one hand, the key characteristics of the problem formulation, mathematical modeling, and solution approaches to DFLP in the last decade and, on the other hand, the inclusion of elements related to the three SSCM pillars, i.e., economic, environmental, and social. Through the resulting taxonomy, the articles were classified to allow current trends and future research guidelines to be discerned in order to ease sustainability-oriented DFLP decision making.

Figure 1 shows the scientific journals where the 44 selected articles were published. Only three of them have published approximately $30 \%$ of the articles that have addressed the DFLP in the last decade.

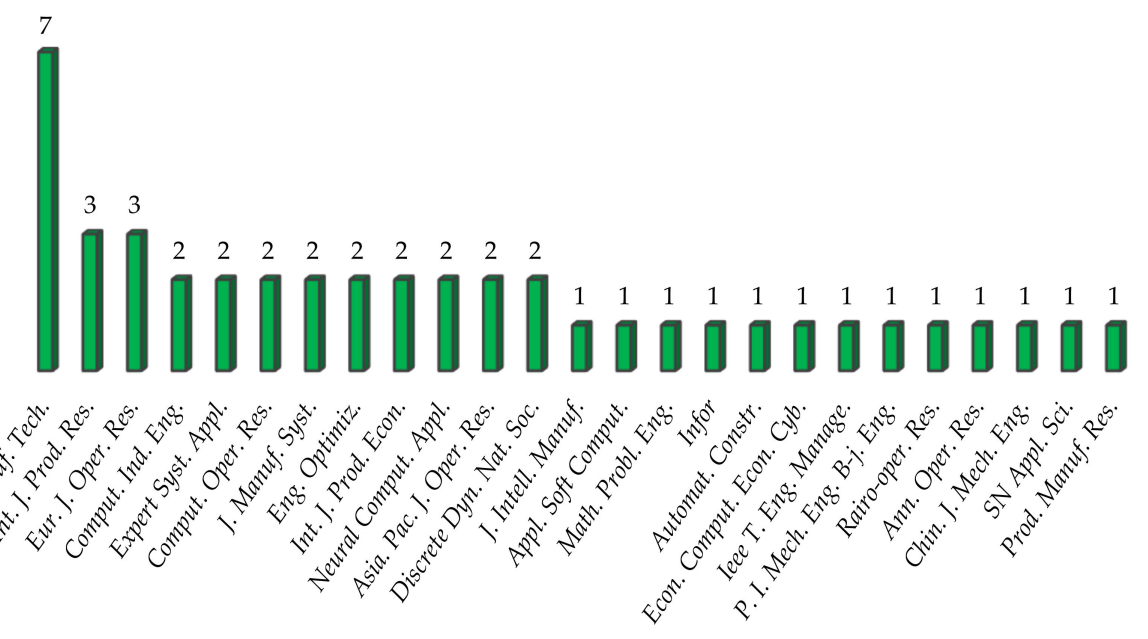

Figure 1. Distribution of publications by scientific journal.

\section{Current Trends in the DFLP Formulation}

Dynamic layouts can be classified as flexible, cyclic, or robust layouts. When planning flexible facility layouts, for each time period an optimal layout is designed to minimize both materials handling and re-layout costs. This category has been the one most frequently addressed in the literature $(86.36 \%)$.

Cyclic layouts were introduced by Kulturel-Konak and Konak [34] as a special case of dynamic layouts, but have not been researched by any other authors to date. In this approach, the planning horizon is divided into $T$ periods, $t=1, \ldots, T$. After period $T$ ends, the material flow matrix between departments returns to its initial state in period $t=1$. In addition to product demand, the area requirements of some departments may also change on a seasonal basis.

In the robust design approach, a single layout is considered for the entire planning horizon with different stochastic demand scenarios. This single design is used for each period and, therefore, there is no rearrangement cost in this approach. A robust layout is not necessarily an optimal layout for a particular time period, but it is suitable over the entire planning horizon since it minimizes the cost of materials handling [35]. Therefore, the robust approach has the advantage of not incurring rearrangement costs and the disadvantage of not representing an optimal design for each time period [36]. This method is appropriate for environments where the cost of rearranging the facilities is high [19], such as in the case of companies that require heavy machinery for the development of their operations. Despite its importance, over the last ten years, little coverage has been given to this approach in the DFLP-related literature (11.36\%).

Table 1 shows an overview of how the DFLP has been addressed in the literature. To construct it, the following classification criteria and their respective categories were considered: Problem type: 
G (greenfield layout design), R (re-layout); Planning phase: B (block layout), D (detailed layout); Planning approach: F (flexible layout, C (cyclic layout), R (robust layout); Number of facilities: $\mathrm{S}$ (single-facility), M (multi-facility); Number of floors: S (single-floor), M (multi-floor); Number of departments; Space consideration: B (two-dimensional), T (three-dimensional); Departments shape: R (regular), I (irregular); Departments dimensions: F (fixed), V (flexible); Departments area: E (equal), $\mathrm{U}$ (unequal); Material handling configuration: SRLP (single-row layout problem), DRLP (double-row layout problem), PRLP (parallel-row layout problem), MRLP (multi-row layout problem), LLP (loop layout problem), OFLP (open-field layout problem).

Table 1. Overview of the facility layout problem (FLP) considering a dynamic planning approach.

\begin{tabular}{|c|c|c|c|c|c|c|c|c|c|c|c|}
\hline References & 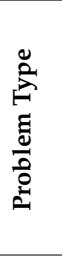 & 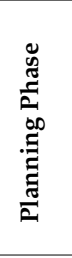 & 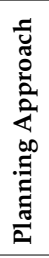 & 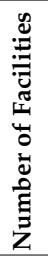 & 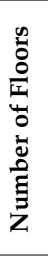 & 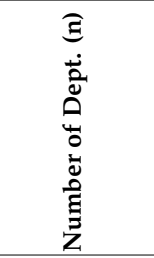 & 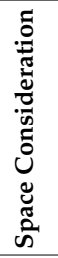 & 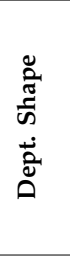 & 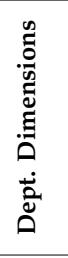 & 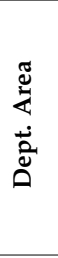 & 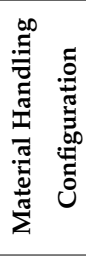 \\
\hline Kheirkhah et al. [2] & G & B & $\mathrm{F}$ & $\mathrm{S}$ & $\mathrm{S}$ & $5 \leq \mathrm{n} \leq 60$ & B & $\mathrm{R}$ & $\mathrm{F}$ & $\mathrm{E}$ & MRLP \\
\hline Moslemipour et al. [19] & G & $\mathrm{B}$ & $\mathrm{R}$ & $\mathrm{S}$ & $\mathrm{S}$ & $2 \leq \mathrm{n} \leq 9$ & $\mathrm{~B}$ & $\mathrm{R}$ & $\mathrm{F}$ & $\mathrm{E}$ & MRLP \\
\hline Emami and Nookabadi [20] & G & B & $\mathrm{F}$ & $\mathrm{S}$ & $\mathrm{S}$ & $4 \leq \mathrm{n} \leq 30$ & B & $\mathrm{R}$ & $\mathrm{F}$ & $\mathrm{E}$ & MRLP \\
\hline Al Hawarneh et al. [21] & G & $\mathrm{B}$ & $\mathrm{F}$ & M & $\mathrm{S}$ & $\mathrm{n}=25$ & B & $\mathrm{R}$ & $\mathrm{F}$ & $\mathrm{E}$ & MRLP \\
\hline Pournaderi et al. [22] & G & B & $\mathrm{F}$ & $\mathrm{S}$ & $\mathrm{S}$ & $\mathrm{n}=6$ & $\mathrm{~B}$ & $\mathrm{R}$ & $\mathrm{F}$ & $\mathrm{E}$ & MRLP \\
\hline Turanoğlu and Akkaya [23] & G & $\mathrm{B}$ & $\mathrm{F}$ & $\mathrm{S}$ & $\mathrm{S}$ & $\mathrm{n}=6,15,30$ & B & $\mathrm{R}$ & $\mathrm{F}$ & $\mathrm{E}$ & MRLP \\
\hline Kulturel-Konak and Konak [34] & G & B & $\mathrm{C}$ & $\mathrm{S}$ & $\mathrm{S}$ & $\mathrm{n}=6,12,15$ & $\mathrm{~B}$ & $\mathrm{R}$ & $\mathrm{V}$ & $\mathrm{U}$ & OFLP \\
\hline Pillai et at. [35] & G & B & $\mathrm{R}$ & $\mathrm{S}$ & $\mathrm{S}$ & $\mathrm{n}=5,15,30$ & $\mathrm{~B}$ & $\mathrm{R}$ & $\mathrm{F}$ & $\mathrm{E}$ & OFLP \\
\hline Peng et al. [36] & G & $\mathrm{B}$ & $\mathrm{R}$ & $\mathrm{S}$ & $\mathrm{S}$ & $8 \leq \mathrm{n} \leq 125$ & $\mathrm{~B}$ & $\mathrm{R}$ & $\mathrm{F}$ & $\mathrm{E}$ & MRLP \\
\hline McKendall and Hakobyan [37] & $\mathrm{G}$ & $\mathrm{B}$ & $\mathrm{F}$ & $\mathrm{S}$ & $\mathrm{S}$ & $6 \leq \mathrm{n} \leq 125$ & $\mathrm{~B}$ & $\mathrm{R}$ & $\mathrm{F}$ & $\mathrm{U}$ & OFLP \\
\hline Yang et al. [38] & $\mathrm{G}$ & B & $\mathrm{F}$ & $\mathrm{S}$ & $\mathrm{S}$ & $\mathrm{n}=10$ & B & $\mathrm{R}$ & $\mathrm{F}$ & $\mathrm{E}$ & MRLP \\
\hline Abedzadeh et al. [39] & G & $\mathrm{B}$ & $\mathrm{F}$ & $\mathrm{S}$ & $\mathrm{S}$ & $4 \leq \mathrm{n} \leq 12$ & $\mathrm{~B}$ & $\mathrm{R}$ & $\mathrm{V}$ & $\mathrm{U}$ & MRLP \\
\hline Guan et al. [40] & $\mathrm{G}$ & B & $\mathrm{F}$ & $\mathrm{S}$ & $\mathrm{S}$ & $\mathrm{n}=10,20,25$ & $\mathrm{~B}$ & $\mathrm{R}$ & $\mathrm{F}$ & $\mathrm{E}$ & MRLP \\
\hline Jolai et al. [41] & G & $\mathrm{B}$ & $\mathrm{F}$ & $\mathrm{S}$ & $\mathrm{S}$ & $\mathrm{n}=6,12$ & $\mathrm{~B}$ & $\mathrm{R}$ & $\mathrm{F}$ & $\mathrm{U}$ & OFLP \\
\hline Kia et al. [42] & G & $\mathrm{B}, \mathrm{D}$ & $\mathrm{F}$ & $\mathrm{S}$ & $\mathrm{S}$ & $4 \leq \mathrm{n} \leq 10$ & B & $\mathrm{R}$ & $\mathrm{F}$ & $\mathrm{E}$ & MRLP \\
\hline McKendall and Liu [43] & G & B & $\mathrm{F}$ & $\mathrm{S}$ & $\mathrm{S}$ & $6 \leq \mathrm{n} \leq 30$ & $\mathrm{~B}$ & $\mathrm{R}$ & $\mathrm{F}$ & $\mathrm{E}$ & MRLP \\
\hline Azimi and Saberi [44] & G & B & $\mathrm{F}$ & $\mathrm{S}$ & $\mathrm{S}$ & $\mathrm{n}=6,15,30$ & B & $\mathrm{R}$ & $\mathrm{F}$ & $\mathrm{U}$ & MRLP \\
\hline Hosseini-Nasab and Emami [45] & G & B & $\mathrm{F}$ & $\mathrm{S}$ & $\mathrm{S}$ & $\mathrm{n}=6,15,30$ & B & $\mathrm{R}$ & $\mathrm{F}$ & $\mathrm{E}$ & MRLP \\
\hline Kaveh et al. [46] & G & $\mathrm{B}$ & $\mathrm{F}$ & $S$ & $\mathrm{~S}$ & $n=6$ & $\mathrm{~B}$ & $\mathrm{R}$ & $\mathrm{F}$ & $\mathrm{E}$ & MRLP \\
\hline Kia et al. [47] & G & $\mathrm{D}$ & $\mathrm{F}$ & $\mathrm{S}$ & $\mathrm{S}$ & $\mathrm{n}=8,10,12$ & B & $\mathrm{R}$ & $\mathrm{F}$ & $\mathrm{E}$ & MRLP \\
\hline Mazinani et al. [48] & G & B & $\mathrm{F}$ & $\mathrm{S}$ & $\mathrm{S}$ & $10 \leq \mathrm{n} \leq 20$ & B & $\mathrm{R}$ & $\mathrm{F}, \mathrm{V}$ & $\mathrm{U}$ & MRLP \\
\hline Samarghandi et al. [49] & G & B & $\mathrm{F}$ & $\mathrm{S}$ & $\mathrm{S}$ & $10 \leq \mathrm{n} \leq 30$ & B & $\mathrm{R}$ & $\mathrm{F}$ & $\mathrm{U}$ & MRLP \\
\hline Chen [50] & G & B & $\mathrm{F}$ & $S$ & $\mathrm{~S}$ & $\mathrm{n}=6,15,30$ & B & $\mathrm{R}$ & $\mathrm{F}$ & $\mathrm{E}$ & MRLP \\
\hline Bozorgi et al. [51] & G & B & $\mathrm{F}$ & $S$ & $\mathrm{~S}$ & $6 \leq n \leq 30$ & B & $\mathrm{R}$ & $\mathrm{F}$ & $\mathrm{E}$ & SRLP \\
\hline Chen and Lo [52] & $\mathrm{G}$ & B & $\mathrm{F}$ & $S$ & $\mathrm{~S}$ & $6 \leq \mathrm{n} \leq 20$ & $\mathrm{~B}$ & $\mathrm{R}$ & $\mathrm{F}$ & $\mathrm{E}$ & MRLP \\
\hline Hosseini et al. [53] & G & B & $\mathrm{F}$ & $\mathrm{S}$ & $\mathrm{S}$ & $6 \leq \mathrm{n} \leq 30$ & B & $\mathrm{R}$ & $\mathrm{F}$ & $\mathrm{E}$ & MRLP \\
\hline Kia et al. [54] & $\mathrm{G}, \mathrm{R}$ & B & $\mathrm{F}$ & $\mathrm{S}$ & M & $10 \leq \mathrm{n} \leq 80$ & B & $\mathrm{R}$ & $\mathrm{F}$ & $\mathrm{E}$ & MRLP \\
\hline Nematian [55] & G & B & $\mathrm{R}$ & $\mathrm{S}$ & $\mathrm{S}$ & $4 \leq \mathrm{n} \leq 15$ & B & $\mathrm{R}$ & $\mathrm{F}$ & $\mathrm{U}$ & SRLP \\
\hline Pourvaziri and Naderi [56] & G & $\mathrm{B}$ & $\mathrm{F}$ & $\mathrm{S}$ & $\mathrm{S}$ & $6 \leq \mathrm{n} \leq 30$ & B & $\mathrm{R}$ & $\mathrm{F}$ & $\mathrm{E}$ & MRLP \\
\hline Derakhshan and Wong [57] & G & B & $\mathrm{F}$ & $\mathrm{S}$ & $\mathrm{S}$ & $\mathrm{n}=8,11,20$ & B & $\mathrm{R}$ & $\mathrm{F}$ & $\mathrm{U}$ & OFLP \\
\hline Li et al. [58] & $\mathrm{G}, \mathrm{R}$ & B & $\mathrm{F}$ & $\mathrm{S}$ & $\mathrm{S}$ & $\mathrm{n}=27$ & $\mathrm{~B}$ & $\mathrm{R}$ & $\mathrm{F}$ & $\mathrm{E}$ & MRLP \\
\hline Ulutas and Islier [59] & G & B & $\mathrm{F}$ & $\mathrm{S}$ & $\mathrm{S}$ & $\mathrm{n}=54$ & B & $\mathrm{R}$ & $\mathrm{F}$ & $\mathrm{E}$ & MRLP \\
\hline Zarea et al. [60] & G & B & $\mathrm{R}$ & $\mathrm{S}$ & $\mathrm{S}$ & $\mathrm{n}=9$ & B & $\mathrm{R}$ & $\mathrm{F}$ & $\mathrm{E}$ & MRLP \\
\hline Hosseini and Seifbarghy [61] & G & B & $\mathrm{F}$ & $\mathrm{S}$ & $\mathrm{S}$ & $6 \leq \mathrm{n} \leq 15$ & B & $\mathrm{R}$ & $\mathrm{F}$ & $\mathrm{E}$ & MRLP \\
\hline Pourvaziri and Pierreval [62] & G & B & $\mathrm{F}$ & $\mathrm{S}$ & $\mathrm{S}$ & $\mathrm{n}=8$ & B & $\mathrm{R}$ & $\mathrm{F}$ & $\mathrm{E}$ & MRLP \\
\hline Tayal and Singh [63] & G & $\mathrm{D}$ & $\mathrm{F}$ & $\mathrm{S}$ & $\mathrm{S}$ & $\mathrm{n}=12$ & B & $\mathrm{R}$ & $\mathrm{F}$ & $\mathrm{E}$ & SRLP \\
\hline Kumar and Singh [64] & G & $\mathrm{B}, \mathrm{D}$ & $\mathrm{F}$ & $\mathrm{S}$ & $\mathrm{S}$ & $\mathrm{n}=5,7,8$ & B & $\mathrm{R}$ & $\mathrm{F}$ & $\mathrm{E}$ & MRLP \\
\hline Liu et al. [65] & G & B & $\mathrm{F}$ & $\mathrm{S}$ & $\mathrm{S}$ & $6 \leq \mathrm{n} \leq 20$ & B & $\mathrm{R}$ & $\mathrm{F}$ & $\mathrm{U}$ & OFLP \\
\hline Vitayasak et al. [66] & G & $\mathrm{B}$ & $\mathrm{F}$ & $\mathrm{S}$ & $\mathrm{S}$ & $10 \leq \mathrm{n} \leq 50$ & B & $\mathrm{R}$ & $\mathrm{F}$ & $\mathrm{U}$ & MRLP \\
\hline Xiao et al. [67] & G & B & $\mathrm{F}$ & $\mathrm{S}$ & $\mathrm{S}$ & $10 \leq \mathrm{n} \leq 35$ & $\mathrm{~B}$ & $\mathrm{R}, \mathrm{I}$ & $\mathrm{V}$ & $\mathrm{U}$ & OFLP \\
\hline Kulturel-Konak [68] & G & $\mathrm{B}$ & $\mathrm{F}$ & $\mathrm{S}$ & $\mathrm{S}$ & $12 \leq \mathrm{n} \leq 25$ & $\mathrm{~B}$ & $\mathrm{R}$ & $\mathrm{V}$ & $\mathrm{U}$ & OFLP \\
\hline Li et al. [69] & G & $\mathrm{D}$ & $\mathrm{F}$ & $\mathrm{S}$ & $\mathrm{S}$ & $\mathrm{n}=12$ & $\mathrm{~B}$ & $\mathrm{R}$ & $\mathrm{F}$ & $\mathrm{U}$ & OFLP \\
\hline Vitayasak and Pongcharoen [70] & G & $\mathrm{D}$ & $\mathrm{F}$ & $\mathrm{S}$ & $\mathrm{S}$ & $10 \leq \mathrm{n} \leq 50$ & B & $\mathrm{R}$ & $\mathrm{F}$ & $\mathrm{U}$ & MRLP \\
\hline Wei et al. [71] & G & $\mathrm{D}$ & $\mathrm{F}$ & $\mathrm{S}$ & $\mathrm{S}$ & $\mathrm{n}=10$ & B & $\mathrm{R}$ & $\mathrm{F}$ & $\mathrm{U}$ & OFLP \\
\hline
\end{tabular}

In the literature, the greenfield layout design has been given greater connotation, although in practice, the problem of existing plants' re-layouts has been more frequent [72]. Among the bibliographic sources herein consulted, only $4.55 \%$ addressed the last-cited problem ( 2 articles). 
Traditionally, most approaches tackling the facilities layout planning have followed the systematic layout planning methodology (SLP) introduced by Muther [73]. A recent study concluded that this was the most appropriate approach to handle facility layout design problems [74]. Like most engineering design problems, SLP methodology is based on a hierarchical approach, starting with a block layout phase and followed by a detailed phase $[75,76]$. However, most of the research available in the DFLP context have addressed both phases separately. Only two works have addressed both phases as part of the same problem [40,63].

Despite the fact that one of the classic principles of facility planning is to obtain the maximum possible use of space inside the industrial plant, the consideration of three-dimensional space in its planning has been scarcely addressed in the context of the DFLP. In fact, all the articles reviewed have considered space only from a two-dimensional point of view.

When planning dynamic layouts, departments may be considered equal-area or unequal-area [77]. The selection of discrete or continuous optimization models to generate layout alternatives relies on this assumption [78]. The equal-area department problem is usually addressed using discrete optimization models to optimally assign $n$ departments to a set of $n$ predefined locations [67]. Conversely, in the unequal-area layout problem, continuous mathematical models are preferred [28,37,48]. Approximately, $64 \%$ of the revised literature considered equal-area departments, and the remaining $36 \%$ chose the unequal-area approach.

In terms of shape, departments can be regular or irregular [79]. The first case, which refers to rectangular-shaped departments $[6,80]$, has been the most common in the revised literature $(98 \%)$.

There are two categories of department size: Fixed or flexible [67]. In the first case, the width and length of the departments do not vary during the allocation process, while in the second one, they vary in a pre-established interval. Among the articles that handled flexible dimensions, such variability was controlled using aspect ratios, which are the proportion between the longest and shortest side of each department [6].

According to the materials handling system configuration, the MRLP is the most widespread approach in the consulted literature (70.45\% of the cases). In contrast, less attention has been paid to the OFLP and the SRLP with $22.73 \%$ and $6.82 \%$ of the cases, respectively. In the last 10 years, the DFLP has not been addressed for any of the other known configurations.

Most published research has considered the layout design in the single building and/or single floor context. However, large companies often operate on more than one floor, and even in several buildings. Only one work has simultaneously planned a layout for several buildings [21], and only one article has considered several floors [54].

\section{Current Trends in the Mathematical Modeling of the DFLP}

The DFLP has been classified as an NP-hard optimization problem (non-deterministic polynomial time-hard problem) because there is no exact technique that optimally solves the problem in a reasonable polynomial time Heuristics for the dynamic facility layout problem with unequal-area departments $[37,52,81]$. However, despite this degree of complexity, different authors have provided acceptable solutions in realistic calculation times, applying everything from exact techniques to state-of-the-art heuristic algorithms.

Table 2 shows the characteristics of the modeling approaches to the DFLP identified in the revised literature. Each of the 44 contributions was classified according to the type of mathematical model; the type of objective function: $\mathrm{SO}$ (single objective), $\mathrm{MO}$ (multi-objective); the demand consideration: $\mathrm{C}$ (certain), $\mathrm{U}$ (uncertain); the type of data: $\mathrm{D}$ (deterministic), $\mathrm{N}$ (non-deterministic); the distance metric: $\mathrm{R}$ (rectilinear), E (Euclidean), FD (flow path-based distance); and the solution approach: E (exact), A (approximate), S (stochastic), H (hybrid), M (matheuristic). Similarly, for each case, a description of the objective functions is given, as well as the constraints considered in the formulation of the DFLP. 
Table 2. Characteristics of the mathematical models used in the formulation of the dynamic facility layout problem (DFLP).

\begin{tabular}{|c|c|c|c|c|c|c|c|c|}
\hline References & 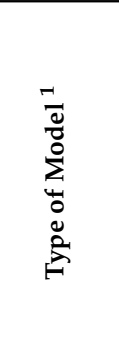 & 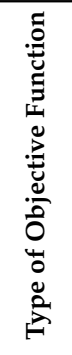 & 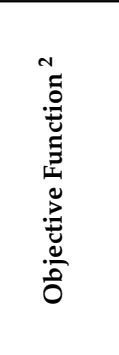 & 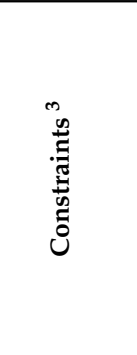 & 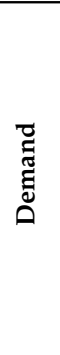 & 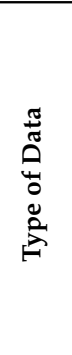 & 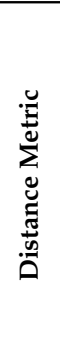 & 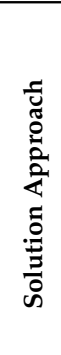 \\
\hline Kheirkhah et al. [2] & BLPM & $\mathrm{MO}$ & $a, b, g$ & $2,6,15$ & $\mathrm{C}$ & $\mathrm{D}$ & $\mathrm{R}$ & $\mathrm{A}$ \\
\hline Moslemipour et al. [19] & QAP & SO & $\mathrm{a}$ & 2 & $\mathrm{U}$ & $\mathrm{D}$ & $\mathrm{R}$ & $\mathrm{E}, \mathrm{A}$ \\
\hline Emami and Nookabadi [20] & QAP & $\mathrm{MO}$ & $a, b, L$ & 2 & $\mathrm{C}$ & $\mathrm{D}$ & $\mathrm{R}$ & A \\
\hline Al Hawarneh et al. [21] & LIP & $\mathrm{SO}$ & $\mathrm{a}, \mathrm{b}$ & 2,6 & C & $\mathrm{D}$ & E & A \\
\hline Pournaderi et al. [22] & QAP & $\mathrm{MO}$ & $a, b$ & 1,15 & $\mathrm{C}$ & $\mathrm{D}$ & $\mathrm{R}$ & A \\
\hline Turanoğlu and Akkaya [23] & QAP & SO & $a, b$ & 2 & $\mathrm{C}$ & $\mathrm{D}$ & $\mathrm{R}$ & A \\
\hline Kulturel-Konak and Konak [34] & MINLP & SO & $a, b$ & 2,6 & $\mathrm{C}$ & $\mathrm{D}$ & $\mathrm{R}$ & M \\
\hline Pillai et at. [35] & QAP & $\mathrm{MO}$ & $a, b$ & 2 & $\mathrm{C}$ & $\mathrm{D}$ & $\mathrm{R}$ & A \\
\hline Peng et al. [36] & QAP & $\mathrm{SO}$ & $a, b$ & 15 & $\mathrm{U}$ & $\mathrm{N}$ & $\mathrm{R}$ & A,S \\
\hline McKendall and Hakobyan [37] & MILP & SO & $a, b$ & $2,6,9$ & $\mathrm{C}$ & $\mathrm{D}$ & $\mathrm{R}$ & A \\
\hline Yang et al. [38] & MILP & SO & $a, b$ & 2 & $\mathrm{C}$ & $\mathrm{D}$ & $\mathrm{R}$ & A \\
\hline Abedzadeh et al. [39] & MILP & $\mathrm{MO}$ & $a, b, f, L$ & $2,6,8$ & C & $\mathrm{D}$ & $\mathrm{R}$ & A \\
\hline Guan et al. [40] & QAP & SO & $\mathrm{a}, \mathrm{b}$ & 2 & $\mathrm{C}$ & $\mathrm{D}$ & FD & A \\
\hline Jolai et al. [41] & MINLP & $\mathrm{MO}$ & $\mathrm{a}, \mathrm{b}, \mathrm{L}, \mathrm{M}$ & $2,6,7,9$ & $\mathrm{C}$ & $\mathrm{D}$ & $\mathrm{R}$ & A \\
\hline Kia et al. [42] & MINLP & $\mathrm{SO}$ & $a, b, h$ & 2,3 & $\mathrm{C}$ & $\mathrm{D}$ & $\mathrm{R}$ & $\mathrm{E}, \mathrm{A}$ \\
\hline McKendall and Liu [43] & QAP & SO & $\mathrm{a}, \mathrm{b}$ & 2 & $\mathrm{C}$ & $\mathrm{D}$ & $\mathrm{R}$ & A \\
\hline Azimi and Saberi [44] & QAP & SO & $a, b$ & 2 & C & $\mathrm{D}$ & $\mathrm{R}$ & A \\
\hline Hosseini-Nasab and Emami [45] & QAP & SO & $a, b$ & 2 & $\mathrm{C}$ & $\mathrm{D}$ & $\mathrm{R}$ & A \\
\hline Kaveh et al. [46] & QAP & SO & $a, b$ & 2 & $\mathrm{U}$ & $\mathrm{D}, \mathrm{N}$ & $\mathrm{R}$ & $\mathrm{A}, \mathrm{S}$ \\
\hline Kia et al. [47] & MINLP & SO & $\mathrm{a}, \mathrm{b}, \mathrm{h}$ & $2,3,12,13$ & $\mathrm{C}$ & $\mathrm{D}$ & $\mathrm{R}$ & $\mathrm{E}, \mathrm{A}$ \\
\hline Mazinani et al. [48] & MILP & SO & $\mathrm{a}, \mathrm{b}$ & $2,6,8,9$ & $\mathrm{C}$ & $\mathrm{D}$ & $\mathrm{R}$ & A \\
\hline Samarghandi et al. [49] & NLP & $\mathrm{MO}$ & $a, b, L$ & 2 & $\mathrm{U}$ & $\mathrm{D}, \mathrm{N}$ & $\mathrm{R}$ & A \\
\hline Chen [50] & QAP & SO & $\mathrm{a}, \mathrm{b}$ & 2 & $\mathrm{C}$ & $\mathrm{D}$ & $\mathrm{R}$ & A \\
\hline Bozorgi et al. [51] & QAP & $\mathrm{MO}$ & $\mathrm{a}, \mathrm{b}, \mathrm{L}, \mathrm{M}$ & 2 & $\mathrm{C}$ & $\mathrm{D}$ & E & A \\
\hline Chen and Lo [52] & QAP & $\mathrm{MO}$ & $\mathrm{a}, \mathrm{b}, \mathrm{L}$ & 2 & $\mathrm{C}$ & $\mathrm{D}$ & $\mathrm{R}$ & A \\
\hline Hosseini et al. [53] & QAP & SO & $a, b$ & 2 & $\mathrm{C}$ & $\mathrm{D}$ & $\mathrm{R}$ & A \\
\hline Kia et al. [54] & MILP & SO & $\mathrm{a}, \mathrm{b}, \mathrm{h}$ & \multicolumn{2}{|c|}{ 2,3,11,12,13,04 } & $\mathrm{D}$ & $\mathrm{R}$ & A \\
\hline Nematian [55] & FSPM & SO & a & $2,6,10$ & $\mathrm{C}$ & $\mathrm{N}$ & $\mathrm{R}$ & $\mathrm{H}$ \\
\hline Pourvaziri and Naderi [56] & QAP & SO & $a, b$ & 2 & C & $\mathrm{D}$ & $\mathrm{R}$ & A \\
\hline Derakhshan and Wong [57] & MINLP & SO & $a, b$ & 2,6 & $\mathrm{C}$ & $\mathrm{D}$ & $\mathrm{R}$ & A \\
\hline Li et al. [58] & MINLP & SO & $a, b$ & 1,2 & $\mathrm{C}$ & $\mathrm{D}$ & $\mathrm{R}$ & A \\
\hline Ulutas and Islier [59] & QAP & SO & $a, b$ & 2 & $\mathrm{C}$ & $\mathrm{D}$ & $\mathrm{R}$ & A \\
\hline Zarea et al. [60] & QAP & SO & $a, b$ & 2 & $\mathrm{U}$ & $\mathrm{D}$ & $\mathrm{R}$ & A \\
\hline Hosseini and Seifbarghy [61] & NLP & $\mathrm{MO}$ & $\mathrm{a}, \mathrm{b}, \mathrm{g}$ & $2,15,18$ & C & $\mathrm{D}$ & $\mathrm{R}$ & A \\
\hline Pourvaziri and Pierreval [62] & QAP & $\mathrm{MO}$ & $a, b, g, e$ & $2,4,7,15$ & $\mathrm{U}$ & $\mathrm{D}, \mathrm{N}$ & $\mathrm{R}$ & A \\
\hline Tayal and Singh [63] & QAP & $\mathrm{MO}$ & $\mathrm{a}, \mathrm{b}, \mathrm{d}, \mathrm{i}, \mathrm{L}$ & 2 & $\mathrm{U}$ & $\mathrm{N}$ & $\mathrm{R}$ & A \\
\hline Kumar and Singh [64] & QAP & SO & $a, b$ & 16 & $\mathrm{C}$ & $\mathrm{D}$ & $\mathrm{R}$ & A \\
\hline Liu et al. [65] & MINLP & SO & $a, b$ & 2,6 & $\mathrm{C}$ & $\mathrm{D}$ & $\mathrm{R}$ & $\mathrm{H}$ \\
\hline Vitayasak et al. [66] & LIP & SO & $a, b$ & $2,6,10$ & $\mathrm{U}$ & $\mathrm{D}, \mathrm{N}$ & $\mathrm{R}$ & A \\
\hline Xiao et al. [67] & MILP & SO & $a, b$ & $2,5,6,17$ & $\mathrm{C}$ & $\mathrm{D}$ & $\mathrm{R}$ & A \\
\hline Kulturel-Konak [68] & MINLP & $\mathrm{SO}$ & $a, b$ & $2,5,6,7$ & C & $\mathrm{D}$ & $\mathrm{R}$ & $\mathrm{M}$ \\
\hline Li et al. [69] & NLP & $\mathrm{MO}$ & $a, b, j, k, N$ & $1,2,6$ & C & $\mathrm{D}$ & $\mathrm{R}$ & A \\
\hline Vitayasak and Pongcharoen [70] & LIP & SO & c & 2,6 & $\mathrm{U}$ & $\mathrm{D}$ & $\mathrm{R}$ & A \\
\hline Wei et al. [71] & NLP & $\mathrm{MO}$ & $a, b, N$ & $2,6,10$ & $\mathrm{C}$ & $\mathrm{D}$ & $\mathrm{R}$ & A \\
\hline
\end{tabular}

${ }^{1}$ Type of model: QAP (quadratic assignment problem), BLPM (bi-level programming model), LIP (linear-integer programming), MILP (mixed-integer linear programming), MINLP (mixed-integer non-linear programming), NPL (non-linear programming), FSPM (fuzzy stochastic programming model); ${ }^{2}$ In describing the objective functions, lowercase letters stand for minimization objectives and uppercase letters indicate maximization objectives: $\mathrm{a}$ (materials handling cost), $\mathrm{b}$ (rearrangement cost), $\mathrm{c}$ (flow distance), $\mathrm{d}$ (transport time), e (work in process), $\mathrm{f}$ (aspect ratio), $\mathrm{g}$ (costs related to the material handling equipment), $\mathrm{h}$ (costs related to machinery operations), $\mathrm{i}$ (risk level associated with the hazardous materials and waste path), $\mathrm{j}$ (lost opportunity costs), $\mathrm{k}$ (occupational health/safety risks), L (closeness ratings among departments), M (distance requests among departments), $\mathrm{N}$ (area utilization ratio); ${ }^{3}$ Constraints: 1 (budget), 2 (area), 3 (capacity), 4 (work in process), 5 (distance), 6 (non-overlapping), 7 (pick up and drop off location points), 8 (aspect ratio), 9 (orientation), 10 (clearance among departments), 11 (demand satisfaction), 12 (machine availability), 13 (location of machines), 14 (material flow conservation), 15 (number of material handling devices), 16 (number of machines per department), 17 (symmetry-breaking constraints), 18 (transport time). 
The most widely used mathematical programming approaches in DFLP modeling have been, in decreasing order of frequency: The quadratic assignment problem (QAP) with $45 \%$ of the cases; mixed-integer non-linear programming (MINLP) with 20\%; mixed-integer linear programming (MILP) with approximately 14\%; non-linear programming (NLP) with just over 9\%; and linear-integer programming (LIP) with almost 7\%. However, fuzzy stochastic programming model (FSPM), and bilevel optimization (BLPM), have also been applied, respectively, to the specific cases of SRLP and MRLP configurations.

The mathematical models generally used have been subject to 18 different types of constraints, of which the most widely used, in order of frequency, are: Area restrictions (93.18\%); non overlapping between departments (36.36\%); number of material handling devices $(11.36 \%)$; budget $(6.82 \%)$; capacity $(6.82 \%)$; pick up/drop off point locations $(6.82 \%)$; departments orientation $(6.82 \%)$; and clearance between departments (6.82\%). Moreover, most DFLP optimization models consider a single quantitative objective function that simultaneously involves material handling costs and rearrangement costs. However, for some industrial and service companies, qualitative factors like closeness ratings among departments, layout flexibility or safety issues may be more relevant. Only $31.82 \%$ of the revised literature have addressed the DFLP with multi-objective optimization models.

The solution approaches applied to the DFLP can be generally categorized into exact, approximate, stochastic, and intelligent [6]. In addition, matheuristic and hybrid approaches have been added to these categories, as they have been identified among the solution approaches employed in the revised literature.

Given the NP-hard nature of the problem, very few authors have managed to find optimal solutions, and those who have attempted to have used the branch and bound method [42,47] or dynamic programming for a few machines or departments [19]. Therefore, most authors have considered seeking suboptimal solutions for larger problems by applying heuristic algorithms. Among these, the most popular methods have been metaheuristic algorithms. In the reviewed literature, 17 of these algorithms were applied to solve DFLP optimization models, of which the most frequent were simulated annealing, genetic algorithms, particle swarm optimization, variable neighborhood search, and tabu search with $16,13,6,5$, and 4 papers, respectively. A summary of the above analysis is shown in Table 3.

It is also important to emphasize the growing tendency to focus the DFLP analysis on more powerful resolution algorithms applied in fictitious problems or classic test problems that do not respond to real-world case studies. Conversely, the following works have addressed the problem in several industries: Footwear [59]; textile [67]; metalworking [69]; construction [21].

Table 3. Review of metaheuristic algorithms ${ }^{1}$ used in the resolution of the DFLP.

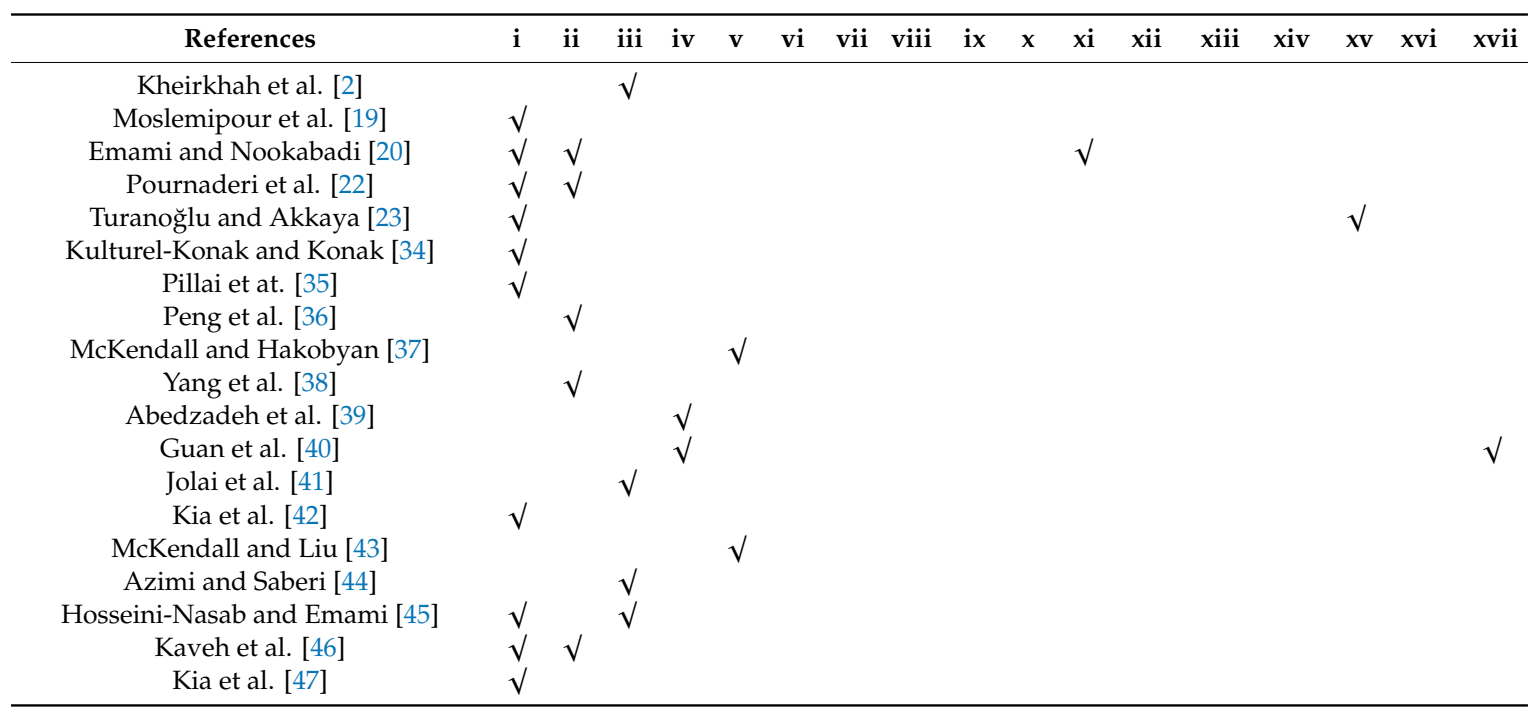


Table 3. Cont.

\begin{tabular}{|c|c|c|c|c|c|c|c|c|c|c|c|c|c|c|c|c|c|}
\hline References & $\mathbf{i}$ & ii & iii & iv & $\mathbf{v}$ & vi & vii & viii & ix & $\mathbf{x}$ & $\mathbf{x i}$ & xii & xiii & xiv & $\mathbf{x v}$ & xvi & xvii \\
\hline Mazinani et al. [48] & & $\sqrt{ }$ & & & & & & & & & & & & & & & \\
\hline Samarghandi et al. [49] & & $\sqrt{ }$ & $\sqrt{ }$ & $\sqrt{ }$ & $\sqrt{ }$ & & & & & & & & & & & & \\
\hline Bozorgi et al. [51] & & & & & $\sqrt{ }$ & & & & & & & & & & & & \\
\hline Chen and Lo [52] & & & & & & $\sqrt{ }$ & & & & & & & & & & & \\
\hline Hosseini et al. [53] & $\sqrt{ }$ & & & $\sqrt{ }$ & & & & & & & & $\sqrt{ }$ & & & & & \\
\hline Derakhshan and Wong [57] & & & $\sqrt{ }$ & & & & & & & & & & & & & & \\
\hline Li et al. [58] & $\sqrt{ }$ & & & & & & & & & & & & & & & & \\
\hline Ulutas and Islier [59] & & & & & & & & $\sqrt{ }$ & & & & & & & & & \\
\hline Zarea et al. [60] & & $\sqrt{ }$ & & & & & & & & & & & & & & & \\
\hline Hosseini and Seifbarghy [61] & & & & & & & & & & & & & $\sqrt{ }$ & & & & \\
\hline Kulturel-Konak [68] & $\sqrt{ }$ & & & $\sqrt{ }$ & & & & & & & & & & & & & \\
\hline Li et al. [69] & & & & & & & $\sqrt{ }$ & & & & & & & & & & \\
\hline Vitayasak and Pongcharoen [70] & & $\sqrt{ }$ & & & & & & & & & & & & & & $\sqrt{ }$ & \\
\hline Wei et al. [71] & & $\sqrt{ }$ & & & & & & & & & & & & & & & \\
\hline
\end{tabular}

${ }^{1}$ i (simulated annealing), ii (genetic algorithms), iii (particle swarm optimization), iv (variable neighborhood search), $\mathrm{v}$ (tabu search), vi (ant colony optimization), vii (artificial bee colony algorithm), viii (artificial immune system), ix (firefly algorithm), x (backtracking search algorithm), xi (differential evolution), xii (imperialist competitive algorithm), xiii (water flow-like algorithm), xiv (problem evolution algorithm), xv (bacterial foraging optimization), xvi (teaching-learning-based optimization), xvii (electromagnetism-like mechanism).

\section{Contributions of Dynamic Facility Layout Planning to Supply Chain Sustainability}

This section discusses how research into dynamic facility layout planning has addressed the triple bottom line of SSCM.

As shown in Table 4, the 44 analyzed articles focused mainly on the economic dimension, and only $9 \%$ simultaneously addressed socio-economic aspects. Aspects related to the environmental dimension of sustainability were not explicitly identified in the revised literature.

Table 4. Aspects related to the economic (E) and social (S) dimensions of sustainability in the formulation of DFLP.

\begin{tabular}{|c|c|c|c|}
\hline References & $\mathbf{E}$ & $\mathbf{S}$ & Description \\
\hline Kheirkhah et al. [2] & $\sqrt{ }$ & & $\begin{array}{l}\text { (1) Minimization of materials handling costs and facility } \\
\text { rearrangement costs. (2) Minimization of the need for new } \\
\text { material handling devices during peak demand periods. } \\
\text { (3) Minimization of the number of idle material handling devices } \\
\text { during low demand periods. }\end{array}$ \\
\hline Moslemipour et al. [19] & $\sqrt{ }$ & & (1) Minimization of materials handling costs. \\
\hline Emami and Nookabadi [20] & $\sqrt{ }$ & & $\begin{array}{c}\text { (1) Minimization of materials handling costs and facility } \\
\text { rearrangement costs. }\end{array}$ \\
\hline Al Hawarneh et al. [21] & $\sqrt{ }$ & & $\begin{array}{c}\text { (1) Minimization of materials handling costs and facility } \\
\text { rearrangement costs. }\end{array}$ \\
\hline Pournaderi et al. [22] & $\sqrt{ }$ & & $\begin{array}{l}\text { (1) Minimization of materials handling costs and facility } \\
\text { rearrangement costs. (2) Reduction in the number of material } \\
\text { handling devices needed. (3) Consideration of budget limitations } \\
\text { when planning the layout design. }\end{array}$ \\
\hline Turanoğlu and Akkaya [23] & $\sqrt{ }$ & & $\begin{array}{c}\text { (1) Minimization of materials handling costs and facility } \\
\text { rearrangement costs. }\end{array}$ \\
\hline Kulturel-Konak and Konak [34] & $\sqrt{ }$ & & $\begin{array}{c}\text { (1) Minimization of materials handling costs and facility } \\
\text { rearrangement costs. }\end{array}$ \\
\hline Pillai et at. [35] & $\sqrt{ }$ & & $\begin{array}{c}\text { (1) Minimization of materials handling costs and facility } \\
\text { rearrangement costs. }\end{array}$ \\
\hline Peng et al. [36] & $\sqrt{ }$ & & $\begin{array}{l}\text { (1) Minimization of materials handling costs and facility } \\
\text { rearrangement costs. (2) Reduction in the number of material } \\
\text { handling devices needed. }\end{array}$ \\
\hline
\end{tabular}


Table 4. Cont.

\begin{tabular}{|c|c|c|c|}
\hline References & $\mathrm{E}$ & $\mathrm{S}$ & Description \\
\hline McKendall and Hakobyan [37] & $\sqrt{ }$ & & $\begin{array}{c}\text { (1) Minimization of materials handling costs and facility } \\
\text { rearrangement costs. }\end{array}$ \\
\hline Yang et al. [38] & $\sqrt{ }$ & & $\begin{array}{c}\text { (1) Minimization of materials handling costs and facility } \\
\text { rearrangement costs. }\end{array}$ \\
\hline Abedzadeh et al. [39] & $\sqrt{ }$ & & $\begin{array}{l}\text { (1) Minimization of materials handling costs and facility } \\
\text { rearrangement costs. }\end{array}$ \\
\hline Guan et al. [40] & $\sqrt{ }$ & & $\begin{array}{l}\text { (1) Minimization of the materials handling costs and facility } \\
\text { rearrangement costs. }\end{array}$ \\
\hline Jolai et al. [41] & $\sqrt{ }$ & $\sqrt{ }$ & $\begin{array}{l}\text { (1) Minimization of materials handling costs and facility } \\
\text { rearrangement costs. (2) Maximization of distance requests among } \\
\text { departments to avoid exposing workers to occupational } \\
\text { health/safety risk factors like noise, heat or vibration. }\end{array}$ \\
\hline Kia et al. [42] & $\sqrt{ }$ & & $\begin{array}{c}\text { (1) Minimization of materials handling costs and facility } \\
\text { rearrangement costs. (2) Minimization of machinery } \\
\text { operations costs. }\end{array}$ \\
\hline McKendall and Liu [43] & $\sqrt{ }$ & & $\begin{array}{l}\text { (1) Minimization of materials handling costs and facility } \\
\text { rearrangement costs. }\end{array}$ \\
\hline Azimi and Saberi [44] & $\sqrt{ }$ & & $\begin{array}{c}\text { (1) Minimization of materials handling costs and facility } \\
\text { rearrangement costs. }\end{array}$ \\
\hline Hosseini-Nasab and Emami [45] & $\sqrt{ }$ & & $\begin{array}{c}\text { (1) Minimization of materials handling costs and facility } \\
\text { rearrangement costs. }\end{array}$ \\
\hline Kaveh et al. [46] & $\sqrt{ }$ & & $\begin{array}{l}\text { (1) Minimization of materials handling costs and facility } \\
\text { rearrangement costs. }\end{array}$ \\
\hline Kia et al. [47] & $\sqrt{ }$ & & $\begin{array}{l}\text { (1) Minimization of materials handling costs and facility } \\
\text { rearrangement costs. (2) Minimization of machinery } \\
\text { operations costs. }\end{array}$ \\
\hline Mazinani et al. [48] & $\sqrt{ }$ & & $\begin{array}{c}\text { (1) Minimization of materials handling costs and facility } \\
\text { rearrangement costs. }\end{array}$ \\
\hline Samarghandi et al. [49] & $\sqrt{ }$ & & $\begin{array}{l}\text { (1) Minimization of materials handling costs and facility } \\
\text { rearrangement costs. }\end{array}$ \\
\hline Chen [50] & $\sqrt{ }$ & & $\begin{array}{l}\text { (1) Minimization of materials handling costs and facility } \\
\text { rearrangement costs. }\end{array}$ \\
\hline Bozorgi et al. [51] & $\sqrt{ }$ & $\sqrt{ }$ & $\begin{array}{l}\text { (1) Minimization of materials handling costs and facility } \\
\text { rearrangement costs. (2) Maximization of distance requests among } \\
\text { departments to avoid exposing workers to occupational } \\
\text { health/safety risk factors like noise or vibration. }\end{array}$ \\
\hline Chen and Lo [52] & $\sqrt{ }$ & & $\begin{array}{l}\text { (1) Minimization of materials handling costs and facility } \\
\text { rearrangement costs. }\end{array}$ \\
\hline Hosseini et al. [53] & $\sqrt{ }$ & & $\begin{array}{c}\text { (1) Minimization of materials handling costs and facility } \\
\text { rearrangement costs. }\end{array}$ \\
\hline Kia et al. [54] & $\sqrt{ }$ & & $\begin{array}{l}\text { (1) Minimization of materials handling costs and facility } \\
\text { rearrangement costs. (2) Minimization of machinery } \\
\text { operations costs. }\end{array}$ \\
\hline Nematian [55] & $\sqrt{ }$ & & (1) Minimization of materials handling costs. \\
\hline Pourvaziri and Naderi [56] & $\sqrt{ }$ & & $\begin{array}{c}\text { (1) Minimization of materials handling costs and facility } \\
\text { rearrangement costs. }\end{array}$ \\
\hline Derakhshan and Wong [57] & $\sqrt{ }$ & & $\begin{array}{c}\text { (1) Minimization of materials handling costs and facility } \\
\text { rearrangement costs. }\end{array}$ \\
\hline Li et al. [58] & $\sqrt{ }$ & & $\begin{array}{l}\text { (1) Minimization of materials handling costs and facility } \\
\text { rearrangement costs. (2) Consideration of budget limitations when } \\
\text { planning the layout design. }\end{array}$ \\
\hline Ulutas and Islier [59] & $\sqrt{ }$ & & $\begin{array}{c}\text { (1) Minimization of materials handling costs and facility } \\
\text { rearrangement costs. }\end{array}$ \\
\hline Zarea et al. [60] & $\sqrt{ }$ & & $\begin{array}{l}\text { (1) Minimization of materials handling costs and facility } \\
\text { rearrangement costs. }\end{array}$ \\
\hline Hosseini and Seifbarghy [61] & $\sqrt{ }$ & & $\begin{array}{l}\text { (1) Minimization of materials handling costs, the machines } \\
\text { rearrangement costs, and the fixed costs related to the material } \\
\text { handling equipment. }\end{array}$ \\
\hline Pourvaziri and Pierreval [62] & $\sqrt{ }$ & & $\begin{array}{l}\text { (1) Minimization of materials handling costs (including costs } \\
\text { generated by the transportation devices while traveling empty) } \\
\text { and machines rearrangement costs. (2) Minimization of work } \\
\text { in process. }\end{array}$ \\
\hline Tayal and Singh [63] & $\sqrt{ }$ & $\sqrt{ }$ & $\begin{array}{l}\text { (1) Minimization of materials handling costs, machines } \\
\text { rearrangement costs and transport time. (2) Minimization of the } \\
\text { risk level associated with hazardous materials and waste paths. }\end{array}$ \\
\hline
\end{tabular}


Table 4. Cont.

\begin{tabular}{|c|c|c|c|}
\hline References & $\mathrm{E}$ & $\mathrm{S}$ & Description \\
\hline Kumar and Singh [64] & $\sqrt{ }$ & & $\begin{array}{l}\text { (1) Minimization of materials handling costs and the } \\
\text { rearrangement costs. (2) Reduction in the number of machines } \\
\text { per department. }\end{array}$ \\
\hline Liu et al. [65] & $\sqrt{ }$ & & $\begin{array}{l}\text { (1) Minimization of the materials handling costs and facility } \\
\text { rearrangement costs. }\end{array}$ \\
\hline Vitayasak et al. [66] & $\sqrt{ }$ & & $\begin{array}{l}\text { (1) Minimization of materials handling costs and facility } \\
\text { rearrangement costs. }\end{array}$ \\
\hline Xiao et al. [67] & $\sqrt{ }$ & & $\begin{array}{c}\text { (1) Minimization of materials handling costs and facility } \\
\text { rearrangement costs. }\end{array}$ \\
\hline Kulturel-Konak [68] & $\sqrt{ }$ & & $\begin{array}{l}\text { (1) Minimization of materials handling costs and facility } \\
\text { rearrangement costs. }\end{array}$ \\
\hline Li et al. [69] & $\sqrt{ }$ & $\sqrt{ }$ & $\begin{array}{l}\text { (1) Minimization of materials handling costs, facility } \\
\text { rearrangement costs (including relocation and setup costs), and } \\
\text { lost opportunity costs during the relocation time. } \\
\text { (2) Consideration of budget limitations when planning the layout } \\
\text { design. (3) Maximization of the area utilization ratio in the } \\
\text { production facility. (4) Implementation of the safe and comfort } \\
\text { human-machine interaction. (5) Minimization of the risk of } \\
\text { workers' physical and mental damage. }\end{array}$ \\
\hline Vitayasak and Pongcharoen [70] & $\sqrt{ }$ & & $\begin{array}{l}\text { (1) Minimization of the flow distance, which has a significant } \\
\text { impact on materials handling costs. }\end{array}$ \\
\hline Wei et al. [71] & $\sqrt{ }$ & & $\begin{array}{l}\text { (1) Minimization of materials handling costs and the equipment } \\
\text { replacement cost. (2) Maximization of the area utilization ratio in } \\
\text { the production facility. }\end{array}$ \\
\hline
\end{tabular}

The optimization of materials handling cost, which equals the sum of the flow-weighted transportation costs between each pair of departments, was the most frequently addressed economic goal when planning facility layouts. Materials handling cost is primarily an efficiency indicator, and one that is difficult to meaningfully transform into a monetary unit [82] and yet, for manufacturing companies, it is reported to account for $20-50 \%$ of the total operational costs [83]. Thus, when engaging layout planning decisions, analysts often prioritize the proximity among those departments, machines, or workstations with a greater material flow intensity to reduce the total production costs and contribute to increase organization competitiveness.

Another economic goal that is frequently considered in the DFLP decision-making context was minimizing the cost of reallocating facilities, workstations, and/or machines between consecutive planning periods when adopting flexible or cyclic layouts ( $95 \%$ of the revised literature).

Aspects related to the social dimension of sustainability in the reviewed literature were related mostly to ensuring safer working environments. In this vein, some authors considered satisfying the minimum safety distance requirements between departments to avoid workers' exposure to safety/occupational health risk factors, such as noise, heat, or vibrations [41,51], while others considered designing waste disposal routes or reducing the associated risks in handling hazardous materials [63]. Another significant contribution was to contemplate a synthetic index to evaluate the physical and psychological loads to which the workers could be exposed in different layout scenarios, apart from their working posture and the level of difficulty to perform tasks [69].

Although no aspects related to the environmental dimension of sustainability are explicitly identified in the revised literature, it is important to point out that certain elements of the environmental dimension are favored implicitly when developing an efficient layout plan. For instance, in an attempt to reduce the distance covered by the workflow to minimize material handling costs, a contribution to reducing fuel and energy use in material handling devices could be made.

\section{Guidelines for Future Research}

In the current industrial context, where transitioning from traditional cost-oriented supply chain to sustainable supply chain is almost mandatory, considering static production conditions such as constant customer demand throughout the planning time horizon is no realistic assumption, but has 
been the most frequently addressed planning strategy in the scientific literature related to FLP [6]. To help to bridge this gap, this article provides some current trends and future research guidelines.

In the revised literature, plant layout decisions in dynamic environments focused exclusively on two of the three performance dimensions that make up the triple bottom line of sustainability: Economic and social. Consequently, future research should address how to incorporate aspects related to the environmental dimension of sustainability (e.g., savings in electricity and fuel use) into the process of designing and evaluating greenfield and brownfield layout plans.

It is also important to stress that despite attempts being made to consider the social dimension of sustainability in dynamic facility layout planning, the authors believe that they are still scarce. Further efforts need to be made include an analysis of physical, chemical, biological, and ergonomic risks when determining closeness priorities among departments machines and workstations. In the same vein, it is worth analyzing to what extent allocation over the industrial floorspace of the elements making up the production/service system could contribute to the humanization of work and to favor workers' (and costumers') well-being, self-fulfillment, and self-esteem; increase intrinsic motivation; reduce physical and mental stress; avoid exposure to psychosocial risks. Undoubtedly, this is a gap that future research should continue to bridge.

When planning flexible and cyclic layouts, future research should consider the opportunity costs incurred while the re-layout is being projected. Future papers should pay more attention to brownfield layout planning.

As most of the scientific literature in the DFLP context deals with block layout and detailed layout separately, it would be more useful in practice for operations managers to consider both phases as part of the same problem with a hierarchical approach. Future research should also prioritize modeling real-world case studies to help to bridge the gap of the limited application of FLP research in practice, as previously noted by Meller et al. [76].

Although one of the classic layout planning principles is space optimization, no research has considered the three-dimensional space to deal with the DFLP. Similarly, future research could model the DFLP by considering material handling system configurations that have not yet been addressed in that context, such as the DRLP, PRLP, and LLP.

Although the research works herein analyzed have generally considered the DFLP in the single building and single floor contexts, large companies often consider more than one property and several floors to undertake their operations. This represents a challenge for DFLP mathematical modeling and suggests a gap that future works must bridge. Likewise, most DFLP optimization models seek to minimize a single objective function of a quantitative nature. Yet in practice, the consideration of quantitative and qualitative factors simultaneously can be decisive for many manufacturing or service enterprises. This certainly implies that the scientific community should pay more attention to the multi-objective mathematical modeling of the DFLP. To this end, the development and application of more powerful matheuristic approaches could constitute a promising resolution strategy.

\section{Conclusions}

In this study, we promoted facility layout planning by taking dynamic environments as an alternate strategy to contribute to supply chain sustainability. Yet despite the popularity of this topic among researchers in the operations management field, we found that knowledge gaps still have to be bridged regarding the balanced inclusion of the dimensions making up the so-called triple bottom line. To date, the scientific community's contributions to decision making in the DFLP context have concentrated primarily on the economic dimension of sustainability, and on the social dimension to a lesser extent. We found no explicit mention of the environmental dimension in the reviewed literature.

The DFLP deals with the search for a set of feasible facility layouts through multiple time periods by minimizing the materials handling and rearrangement costs. To our knowledge reaches, since Moslemipour et al. [24], there has not been published any literature review focused on DFLP. Thus, this study has presented a literature review on the DFLP considering a time window from 
2010 to 2019. Furthermore, we depicted to what extent recent research in the DFLP context has contributed to supply chain sustainability by addressing its three dimensions of performance: Economic, environmental, and social.

The relevant bibliography was collected from the WoS database considering only journal articles. Such publications were filtered based on the authors' critical judgments, discarding those that did not address the problem from the field of operations management. The 44 selected papers were analyzed and synthesized to allow the discerning of current trends and future research guidelines.

In the DFLP-related literature, the greenfield layout design has been given greater connotation than the re-layout problem. Most of the revised researches have addressed the block and detailed phases separately. Multi-row layout problem is the most widespread approach used according to the materials handling system configuration. Most published research has considered the layout design in a single building and a single floor. The most widely used mathematical programming approaches in DFLP modeling have been the quadratic assignment problem and mixed-integer programming. More than two thirds of the revised literature have addressed the DFLP with single-objective optimization models. The applied solution approaches can be categorized into exact, approximate, stochastic, matheuristic, and hybrid methods. Given the NP-hard nature of the DFLP, most authors have tried to solve it by applying metaheuristic algorithms. Among these, the most popular methods were the simulated annealing, genetic algorithms, particle swarm optimization, and variable neighborhood search. Additionally, there is a growing tendency to focus the DFLP analysis on more powerful resolution algorithms applied in fictitious problems that do not respond to real-world case studies.

When making decisions related to facility layout planning, there are several recommendations that operations managers can consider based on this review study. On the one hand, they can understand the unfeasibility of maintaining static layout configurations if they operate in rapidly changing markets. It is possible that by adopting flexible layouts, increased labor productivity and production processes efficiency could compensate for the annual rearrangement costs, which would translate into lower total production costs and the possible adoption of competitive advantages that would lead to higher levels of profitability. Even in the case that the estimated re-layout costs are high due to the operation of heavy machinery, to cite an example, the planning of a robust plant layout could generate the same effect in the medium term. Therefore, diagnosing the productivity and efficiency improvement opportunities associated with the organization of the elements that make up the production or service systems in the physical space can be a crucial strategy to achieve the economic sustainability of companies' operations in the medium and long term.

On the other hand, the results of this study could encourage practitioners to facilitate their layout decision-making from a holistic perspective, not only considering the economic factor but also elements of environmental and social nature, for this way to contribute to sustainable supply chain management. That could also aid in enhancing the company's reputation among current and potential customers, investors, suppliers, government entities, and other interested parties already committed to sustainable development.

Despite its significance, the scientific community and operations management professionals should be aware that this study is not exempt from certain limitations. According to the exclusion criteria indicated in Section 2, this review study focused only on those papers that have addressed DFLP through mathematical optimization models. In this sense, other approaches could also be employed for generating feasible solutions to DFLP, such as analytical approaches based on expert's knowledge or computer-aided planning tools. Another limitation of the study was the collection of research articles published in journals indexed in WoS database. Here, the search could be extended to other highly visible scientific databases such as Scopus, EBSCO, and IEEE Xplore, among others.

The guidelines for future research here identified are: (i) To consider the opportunity costs incurred when planning flexible and cyclic layouts; (ii) to contemplate the brownfield layout planning; (iii) to consider the block layout and the detailed layout phases as part of the same problem with a hierarchical approach; (iv) to prioritize modeling real-world case studies to bridge the gap of the 
limited application of FLP research in practice; (v) to consider the three-dimensional space when dealing with the DFLP; (vi) to develop material handling system configurations that have not yet been addressed in the DFLP context, such as the DRLP, PRLP, and LLP; (vii) to address the DFLP in multi-building and multi-floor contexts; (viii) to formulate multi-objective mathematical models of the DFLP considering quantitative and qualitative factors simultaneously; (ix) to develop and to apply more powerful matheuristic approaches as solution strategies to those models; $(x)$ to integrate the economic, environmental, and social sustainable aspects into DFLP models.

Author Contributions: Authors declare a symmetric contribution to the article in all aspects: conceptualization, methodology, resources, investigation, formal analysis, project administration, supervision, validation, writing-original draft, writing-review and editing. All authors have read and agreed to the published version of the manuscript.

Funding: This research was funded by the Spanish Ministry of Science, Innovation and Universities Project CADS4.0, grant number RTI2018-101344-B-I00; and the Valencian Community ERDF Programme 2014-2020, grant number IDIFEDER/2018/025.

Conflicts of Interest: The authors declare no conflict of interest.

\section{References}

1. Tari, F.G.; Neghabi, H. A new linear adjacency approach for facility layout problem with unequal area departments. J. Manuf. Syst. 2015, 37, 93-103. [CrossRef]

2. Kheirkhah, A.S.; Navidi, H.; Bidgoli, M.M. Dynamic Facility Layout Problem: A New Bilevel Formulation and Some Metaheuristic Solution Methods. IEEE Trans. Eng. Manag. 2015, 62, 1-15. [CrossRef]

3. Altuntas, S.; Selim, H. Facility layout using weighted association rule-based data mining algorithms: Evaluation with simulation. Expert Syst. Appl. 2012, 39, 3-13. [CrossRef]

4. Ku, M.-Y.; Hu, M.H.; Wang, M.-J. Simulated annealing based parallel genetic algorithm for facility layout problem. Int. J. Prod. Res. 2011, 49, 1801-1812. [CrossRef]

5. Navidi, H.; Bashiri, M.; Bidgoli, M.M. A heuristic approach on the facility layout problem based on game theory. Int. J. Prod. Res. 2012, 50, 1512-1527. [CrossRef]

6. Hosseini-Nasab, H.; Fereidouni, S.; Ghomi, S.M.T.F.; Fakhrzad, M.B. Classification of facility layout problems: A review study. Int. J. Adv. Manuf. Technol. 2017, 94, 957-977. [CrossRef]

7. Carter, C.R.; Rogers, D.S. A framework of sustainable supply chain management: Moving toward new theory. Int. J. Phys. Distrib. Logist. Manag. 2008, 38, 360-387. [CrossRef]

8. Carter, C.R.; Washispack, S. Mapping the Path Forward for Sustainable Supply Chain Management: A Review of Reviews. J. Bus. Logist. 2018, 39, 242-247. [CrossRef]

9. Roy, V.; Schoenherr, T.; Charan, P. The thematic landscape of literature in sustainable supply chain management (SSCM). Int. J. Oper. Prod. Manag. 2018, 38, 1091-1124. [CrossRef]

10. Barbosa-Póvoa, A.P.F.D.; Da Silva, C.; Carvalho, A. Opportunities and challenges in sustainable supply chain: An operations research perspective. Eur. J. Oper. Res. 2018, 268, 399-431. [CrossRef]

11. Tonelli, F.; Evans, S.; Taticchi, P. Industrial sustainability: Challenges, perspectives, actions. Int. J. Bus. Innov. Res. 2013, 7, 143. [CrossRef]

12. Sánchez-Flores, R.B.; Cruz-Sotelo, S.E.; Ojeda-Benítez, S.; Ramírez-Barreto, M.E. Sustainable Supply Chain Management-A Literature Review on Emerging Economies. Sustainability 2020, 12, 6972. [CrossRef]

13. Ford, S.; Despeisse, M. Additive manufacturing and sustainability: An exploratory study of the advantages and challenges. J. Clean. Prod. 2016, 137, 1573-1587. [CrossRef]

14. Kamble, S.S.; Gunasekaran, A.; Gawankar, S.A. Sustainable Industry 4.0 framework: A systematic literature review identifying the current trends and future perspectives. Process. Saf. Environ. Prot. 2018, 117, 408-425. [CrossRef]

15. Khuntia, J.; Saldanha, T.J.V.; Mithas, S.; Sambamurthy, V. Information Technology and Sustainability: Evidence from an Emerging Economy. Prod. Oper. Manag. 2018, 27, 756-773. [CrossRef]

16. Roy, S.; Das, M.; Ali, S.M.; Raihan, A.S.; Paul, S.K.; Kabir, G. Evaluating strategies for environmental sustainability in a supply chain of an emerging economy. J. Clean. Prod. 2020, 262, 121389. [CrossRef]

17. Morais, D.O.; Silvestre, B.S. Advancing social sustainability in supply chain management: Lessons from multiple case studies in an emerging economy. J. Clean. Prod. 2018, 199, 222-235. [CrossRef] 
18. Stindt, D. A generic planning approach for sustainable supply chain management - How to integrate concepts and methods to address the issues of sustainability? J. Clean. Prod. 2017, 153, 146-163. [CrossRef]

19. Moslemipour, G.; Lee, T.S.; Loong, Y.T. Performance Analysis of Intelligent Robust Facility Layout Design. Chin. J. Mech. Eng. 2017, 30, 407-418. [CrossRef]

20. Emami, S.; Nookabadi, A.S. Managing a new multi-objective model for the dynamic facility layout problem. Int. J. Adv. Manuf. Technol. 2013, 68, 2215-2228. [CrossRef]

21. Al Hawarneh, A.; Bendak, S.; Ghanim, F. Dynamic facilities planning model for large scale construction projects. Autom. Constr. 2019, 98, 72-89. [CrossRef]

22. Pournaderi, N.; Ghezavati, V.; Mozafari, M. Developing a mathematical model for the dynamic facility layout problem considering material handling system and optimizing it using cloud theory-based simulated annealing algorithm. Sn. Appl. Sci. 2019, 1, 832. [CrossRef]

23. Turanoğlu, B.; Akkaya, G. A new hybrid heuristic algorithm based on bacterial foraging optimization for the dynamic facility layout problem. Expert Syst. Appl. 2018, 98, 93-104. [CrossRef]

24. Moslemipour, G.; Lee, T.S.; Rilling, D. A review of intelligent approaches for designing dynamic and robust layouts in flexible manufacturing systems. Int. J. Adv. Manuf. Technol. 2011, 60, 11-27. [CrossRef]

25. Tebaldi, L.; Bigliardi, B.; Bottani, E. Sustainable Supply Chain and Innovation: A Review of the Recent Literature. Sustainability 2018, 10, 3946. [CrossRef]

26. Tseng, M.-L.; Islam, S.; Karia, N.; Fauzi, F.A.; Afrin, S. A literature review on green supply chain management: Trends and future challenges. Resour. Conserv. Recycl. 2019, 141, 145-162. [CrossRef]

27. Ghobakhloo, M. Industry 4.0, digitization, and opportunities for sustainability. J. Clean. Prod. 2020, 252, 119869. [CrossRef]

28. Boar, A.; Bastida, R.; Marimon, F. A Systematic Literature Review. Relationships between the Sharing Economy, Sustainability and Sustainable Development Goals. Sustainability 2020, 12, 6744. [CrossRef]

29. Denyer, D.; Tranfield, D. Producing a systematic review. In The Sage Handbook of Organizational Research Methods; Sage Publications: London, UK, 2009; pp. 671-689.

30. Novais, L.R.; Maqueira, J.M.; Ortiz, A. A systematic literature review of cloud computing use in supply chain integration. Comput. Ind. Eng. 2019, 129, 296-314. [CrossRef]

31. Masi, D.; Day, S.; Godsell, J. Supply Chain Configurations in the Circular Economy: A Systematic Literature Review. Sustainability 2017, 9, 1602. [CrossRef]

32. Zavala-Alcívar, A.; Verdecho, M.J.; Alfaro-Saiz, J.-J. A Conceptual Framework to Manage Resilience and Increase Sustainability in the Supply Chain. Sustainability 2020, 12, 6300. [CrossRef]

33. Li, K.; Rollins, J.; Yan, E. Web of Science use in published research and review papers 1997-2017: A selective, dynamic, cross-domain, content-based analysis. Scientometrics 2018, 115, 1-20. [CrossRef] [PubMed]

34. Kulturel-Konak, S.; Konak, A. A large-scale hybrid simulated annealing algorithm for cyclic facility layout problems. Eng. Optim. 2014, 47, 963-978. [CrossRef]

35. Pillai, V.M.; Hunagund, I.; Krishnan, K. Design of robust layout for Dynamic Plant Layout Problems. Comput. Ind. Eng. 2011, 61, 813-823. [CrossRef]

36. Peng, Y.; Zeng, T.; Fan, L.; Han, Y.; Xia, B. An Improved Genetic Algorithm Based Robust Approach for Stochastic Dynamic Facility Layout Problem. Discret. Dyn. Nat. Soc. 2018, 2018, 1-8. [CrossRef]

37. McKendall, A.R.; Hakobyan, A. Heuristics for the dynamic facility layout problem with unequal-area departments. Eur. J. Oper. Res. 2010, 201, 171-182. [CrossRef]

38. Yang, C.-L.; Chuang, S.-P.; Hsu, T.-S. A genetic algorithm for dynamic facility planning in job shop manufacturing. Int. J. Adv. Manuf. Technol. 2010, 52, 303-309. [CrossRef]

39. Abedzadeh, M.; Mazinani, M.; Moradinasab, N.; Roghanian, E. Parallel variable neighborhood search for solving fuzzy multi-objective dynamic facility layout problem. Int. J. Adv. Manuf. Technol. 2012, 65, 197-211. [CrossRef]

40. Guan, X.; Dai, X.; Qiu, B.; Li, J. A revised electromagnetism-like mechanism for layout design of reconfigurable manufacturing system. Comput. Ind. Eng. 2012, 63, 98-108. [CrossRef]

41. Jolai, F.; Tavakkoli-Moghaddam, R.; Taghipour, M. A multi-objective particle swarm optimisation algorithm for unequal sized dynamic facility layout problem with pickup/drop-off locations. Int. J. Prod. Res. 2012, 50, 4279-4293. [CrossRef] 
42. Kia, R.; Baboli, A.; Javadian, N.; Tavakkoli-Moghaddam, R.; Kazemi, M.; Khorrami, J. Solving a group layout design model of a dynamic cellular manufacturing system with alternative process routings, lot splitting and flexible reconfiguration by simulated annealing. Comput. Oper. Res. 2012, 39, 2642-2658. [CrossRef]

43. McKendall, A.; Liu, W.-H. New Tabu search heuristics for the dynamic facility layout problem. Int. J. Prod. Res. 2012, 50, 867-878. [CrossRef]

44. Azimi, P.; Saberi, E. An efficient hybrid algorithm for dynamic facility layout problem using simulation technique and PSO. Econ. Comput. Econ. Cybern. Stud. Res. 2013, 47, 109-125.

45. Hosseini-Nasab, H.; Emami, L. A hybrid particle swarm optimisation for dynamic facility layout problem. Int. J. Prod. Res. 2013, 51, 4325-4335. [CrossRef]

46. Kaveh, M.; Dalfard, V.M.; Amiri, S. A new intelligent algorithm for dynamic facility layout problem in state of fuzzy constraints. Neural Comput. Appl. 2013, 24, 1179-1190. [CrossRef]

47. Kia, R.; Javadian, N.; Paydar, M.M.; Saidi-Mehrabad, M. A Simulated Annealing for Intra-Cell Layout Design of Dynamic Cellular Manufacturing Systems With Route Selection, Purchasing Machines And Cell Reconfiguration. Asia Pac. J. Oper. Res. 2013, 30, 1350004. [CrossRef]

48. Mazinani, M.; Abedzadeh, M.; Mohebali, N. Dynamic facility layout problem based on flexible bay structure and solving by genetic algorithm. Int. J. Adv. Manuf. Technol. 2012, 65, 929-943. [CrossRef]

49. Samarghandi, H.; Taabayan, P.; Behroozi, M. Metaheuristics for fuzzy dynamic facility layout problem with unequal area constraints and closeness ratings. Int. J. Adv. Manuf. Technol. 2013, 67, 2701-2715. [CrossRef]

50. Chen, G.Y.-H. A new data structure of solution representation in hybrid ant colony optimization for large dynamic facility layout problems. Int. J. Prod. Econ. 2013, 142, 362-371. [CrossRef]

51. Bozorgi, N.; Abedzadeh, M.; Zeinali, M. Tabu search heuristic for efficiency of dynamic facility layout problem. Int. J. Adv. Manuf. Technol. 2014, 77, 689-703. [CrossRef]

52. Chen, G.Y.-H.; Lo, J.-C. Dynamic Facility Layout with Multi-Objectives. Asia Pac. J. Oper. Res. 2014, 31, 1-26. [CrossRef]

53. Hosseini, S.; Al Khaled, A.; Vadlamani, S. Hybrid imperialist competitive algorithm, variable neighborhood search, and simulated annealing for dynamic facility layout problem. Neural Comput. Appl. 2014, 25, 1871-1885. [CrossRef]

54. Kia, R.; Khaksar-Haghani, F.; Javadian, N.; Tavakkoli-Moghaddam, R. Solving a multi-floor layout design model of a dynamic cellular manufacturing system by an efficient genetic algorithm. J. Manuf. Syst. 2014, 33, 218-232. [CrossRef]

55. Nematian, J. A robust single row facility layout problem with fuzzy random variables. Int. J. Adv. Manuf. Technol. 2014, 72, 255-267. [CrossRef]

56. Pourvaziri, H.; Naderi, B. A hybrid multi-population genetic algorithm for the dynamic facility layout problem. Appl. Soft Comput. 2014, 24, 457-469. [CrossRef]

57. Asl, A.D.; Wong, K.Y. Solving unequal-area static and dynamic facility layout problems using modified particle swarm optimization. J. Intell. Manuf. 2015, 28, 1317-1336. [CrossRef]

58. Li, L.; Li, C.; Ma, H.; Tang, Y. An Optimization Method for the Remanufacturing Dynamic Facility Layout Problem with Uncertainties. Discret. Dyn. Nat. Soc. 2015, 2015, 1-11. [CrossRef]

59. Ulutas, B.; Islier, A.A. Dynamic facility layout problem in footwear industry. J. Manuf. Syst. 2015, 36, 55-61. [CrossRef]

60. Fazlelahi, F.Z.; Pournader, M.; Gharakhani, M.; Sadjadi, S.J. A robust approach to design a single facility layout plan in dynamic manufacturing environments using a permutation-based genetic algorithm. Proc. Inst. Mech. Eng. Part B J. Eng. Manuf. 2016, 230, 2264-2274. [CrossRef]

61. Hosseini, S.S.; Seifbarghy, M. A novel meta-heuristic algorithm for multi-objective dynamic facility layout problem. Rairo Oper. Res. 2016, 50, 869-890. [CrossRef]

62. Pourvaziri, H.; Pierreval, H. Dynamic facility layout problem based on open queuing network theory. Eur. J. Oper. Res. 2017, 259, 538-553. [CrossRef]

63. Tayal, A.; Singh, S.P. Integrating big data analytic and hybrid firefly-chaotic simulated annealing approach for facility layout problem. Ann. Oper. Res. 2016, 270, 489-514. [CrossRef]

64. Kumar, R.; Singh, S.P. A similarity score-based two-phase heuristic approach to solve the dynamic cellular facility layout for manufacturing systems. Eng. Optim. 2017, 49, 1848-1867. [CrossRef]

65. Liu, J.; Wang, D.; He, K.; Xue, Y. Combining Wang-Landau sampling algorithm and heuristics for solving the unequal-area dynamic facility layout problem. Eur. J. Oper. Res. 2017, 262, 1052-1063. [CrossRef] 
66. Vitayasak, S.; Pongcharoen, P.; Hicks, C. A tool for solving stochastic dynamic facility layout problems with stochastic demand using either a Genetic Algorithm or modified Backtracking Search Algorithm. Int. J. Prod. Econ. 2017, 190, 146-157. [CrossRef]

67. Xiao, Y.; Xie, Y.; Kulturel-Konak, S.; Konak, A. A problem evolution algorithm with linear programming for the dynamic facility layout problem-A general layout formulation. Comput. Oper. Res. 2017, 88, $187-207$. [CrossRef]

68. Kulturel-Konak, S. The zone-based dynamic facility layout proble. INFOR 2019, 57, 1-31.

69. Li, J.; Tan, X.; Li, J. Research on Dynamic Facility Layout Problem of Manufacturing Unit Considering Human Factors. Math. Probl. Eng. 2018, 2018,1-13. [CrossRef]

70. Vitayasak, S.; Pongcharoen, P. Performance improvement of Teaching-Learning-Based Optimisation for robust machine layout design. Expert Syst. Appl. 2018, 98, 129-152. [CrossRef]

71. Wei, X.; Yuan, S.; Ye, Y. Optimizing facility layout planning for reconfigurable manufacturing system based on chaos genetic algorithm. Prod. Manuf. Res. 2019, 7, 109-124. [CrossRef]

72. Kulturel-Konak, S. Approaches to uncertainties in facility layout problems: Perspectives at the beginning of the 21st Century. J. Intell. Manuf. 2007, 18, 273-284. [CrossRef]

73. Muther, R. Systematic Layout Planning; Industrial Education Institute: Boston, MA, USA, 1961.

74. Sharma, P.; Singhal, S. Implementation of fuzzy TOPSIS methodology in selection of procedural approach for facility layout planning. Int. J. Adv. Manuf. Technol. 2016, 88, 1485-1493. [CrossRef]

75. Bukchin, Y.; Tzur, M. A new MILP approach for the facility process-layout design problem with rectangular and L/T shape departments. Int. J. Prod. Res. 2014, 52, 7339-7359. [CrossRef]

76. Meller, R.D.; Kirkizoglu, Z.; Chen, W. A new optimization model to support a bottom-up approach to facility design. Comput. Oper. Res. 2010, 37, 42-49. [CrossRef]

77. Feng, J.; Che, A. Novel integer linear programming models for the facility layout problem with fixed-size rectangular departments. Comput. Oper. Res. 2018, 95, 163-171. [CrossRef]

78. Allahyari, M.Z.; Azab, A. Mathematical modeling and multi-start search simulated annealing for unequal-area facility layout problem. Expert Syst. Appl. 2018, 91, 46-62. [CrossRef]

79. Ahmadi, A.; Pishvaee, M.S.; Jokar, M.R.A. A survey on multi-floor facility layout problems. Comput. Ind. Eng. 2017, 107, 158-170. [CrossRef]

80. Drira, A.; Pierreval, H.; Hajri-Gabouj, S. Facility layout problems: A survey. Annu. Rev. Control. 2007, 31, 255-267. [CrossRef]

81. Grobelny, J.; Michalski, R. A novel version of simulated annealing based on linguistic patterns for solving facility layout problems. Knowl. Based Syst. 2017, 124, 55-69. [CrossRef]

82. Hathhorn, J.; Sisikoglu, E.; Sir, M.Y. A multi-objective mixed-integer programming model for a multi-floor facility layout. Int. J. Prod. Res. 2013, 51, 4223-4239. [CrossRef]

83. Tomkins, J.A.; White, J.A.; Bozer, Y.A.; Tanchoco, J.M.A. Facilities Planning, 4th ed.; Wiley and Sons: Hoboken, NJ, USA, 2010.

(C) 2020 by the authors. Licensee MDPI, Basel, Switzerland. This article is an open access article distributed under the terms and conditions of the Creative Commons Attribution (CC BY) license (http://creativecommons.org/licenses/by/4.0/). 